\title{
PEMBERDAYAAN MASYARAKAT DALAM PENGEMBANGAN EKONOMI KREATIF BERBASIS TRI HITA KARANA DI DESA BINAAN ABANG BATU DINDING KECAMATAN KINTAMANI KABUPATEN BANGLI
}

\author{
I Gede Nurjaya ${ }^{1, *}$, Luh Ayu Tirtayani ${ }^{2}$, I Kadek Rai Suwena ${ }^{3}$ \\ 1 Jurusan Pendidikan Bahasa dan Sastra indonesia. Universitas Pendidikan Ganesha, Indonesia \\ 2 Jurusan Pendidikan Anak Usia Dini. Universitas Pendidikan Ganesha, Indonesia \\ 3 Jurusan Pendidikan Ekonomi. Universitas Pendidikan Ganesha, Indonesia
}

\begin{abstract}
Abstrak
Program Desa Binaan di Desa Abang Batu Dinding ini bertujuan 1) Meningkatkan kualitas sumber daya manusia melalui pendidikan nilai karakter anak usia dini dan pelatihan keterampilan usaha mandiri. (2) Meningkatkan kesadaran masyarakat akan potensi alam dan lingkungan memalui kegiatan pembudidayaan ikan mujair dan pertanian organik untuk mewujudkan kesejahteraan masyarakat dan pembangunan berkelanjutan. (3) Mendorong tumbuhnya kreativitas, motivasi dan inovasi masyarakat dalam mengatasi permasalahan yang dihadapi melalui pelatihan pengembangan usaha ekonomi kreatif, seperti pengolahan ikan mujair pasca panen menjadi Abon Mujair, Krupuk Mujair, Bakso Mujair dan pengolahan hasil pertanian seperti bawang menjadi bawang goreng siap saji. (4) Meningkatkan kesadaran masyarakat melalui penyuluhan untuk mendorong terwujudnya kemandirian dan kesejahteraan masyarakat dalam bidang sistem pemasaran hasil sumber daya alam yang ada di Desa Abang Batu Dinding Kecamatan Kintamani. Berdasarkan pada permasalahan prioritas yang ada, maka solusi yang ditawarkan melalui desa binaan ini menggunakan metode sebagai berikut : Partisipatory Rural Appraisal (PRA) yaitu suatu sistem untuk menyusun dan mengembangkan program operasional dalam pembangunan tingkat desa. Enthrepreneurship Capasity Building (ECB), metode ini berkaitan erat dengan kemampuan beriwirausahan dari masyarakat, Teknologi Tepat Guna (TTG), yaitu metode yang dirancang bagi suatu masyarakat tertentu agar dapat disesuaikan dengan aspek-aspek lingkungan, keetisan, kebudayaan, sosial, politik dan ekonomi masyarakat bersangkutan.
\end{abstract}

\section{Pendahuluan}

Desa Abang Batu Dinding terletak pada ketinggian 867 sampai 1115 meter di atas permukaan air laut, dengan curah hujan rata-rata $1879 \mathrm{~mm} /$ tahun, dan suhu udara rata-rata $20^{\circ} \mathrm{C}$ sampai $26^{\circ} \mathrm{C}$, dengan luas wilayah Desa Abang Batu Dindingadalah 987 Ha, yang pemanfaatannya adalah Pemukiman umum: 52 Ha, Ladang/Kebun: 735,00 Ha, Hutan Lindung: 143,00 Ha, Kuburan: 4,00 Ha, dan Bangunan Umum: 15,00 Ha. Dengan julmlah penduduk 5.668 Jiwa atau $255 \mathrm{KK}$, yang terdiri dari Laki-laki: 2.227 Jiwa dan Perempuan: 3.141Jiwa. Adapun batas-batas desa adalah sebagai berikut. Sebelah Utara : Desa Pingan, sebelah Selatan: Desa Kedisan, sebelah Barat: Desa Desa Batur dan Desa Kintamani, sebelah Timur: Danau Batur. Sementara orbitasi desa dengan pusat adalah: Ke Ibu Kota Kecamatan Kintamani: 9 Km, Ke Ibu Kota Kabupaten Bangli: $25 \mathrm{Km}$, Ke Ibu Kota Propinsi Bali: $78 \mathrm{Km}$. Mata pencaharian masyarakat Desa Abang Batu Dinding adalah 53\% bermata pencaharian pertani, $17 \%$ nelayan, $9 \%$ pedagang, $2 \%$ Pegawai Negeri Sipil dan 2\% pengerajin dan 14\% buruh bangunan, 3\% lain-lain (Monografi Desa Abang Batu Dinding, 2012). Dari jumlah penduduk tersebut, 79,83\% merupakan angkatan kerja produktif. Ini menunjukkan bahwa potensi sumberdaya manusia yang ada di Desa Abang Batu Dindingsangat menjanjikan. Namun, pendapatan masyarakat masih rendah (rata-rata pendapatan penduduk Rp. 457.000,-), padahal potensi yang dapat dikembangkan sangat banyak, seperti: pertanian, perikanan, peternakan, kerajinan/industri rumah tangga dan pariwista.

* Corresponding author

E-mail Addresses gedenurjaya@gmail.com (I Gede Nurjaya), ayu.tirtayani@undiksha.ac.id (Luh Ayu Tirtayani), kadek_suwena@yahoo.co.id (I Kadek Rai Suwena) 


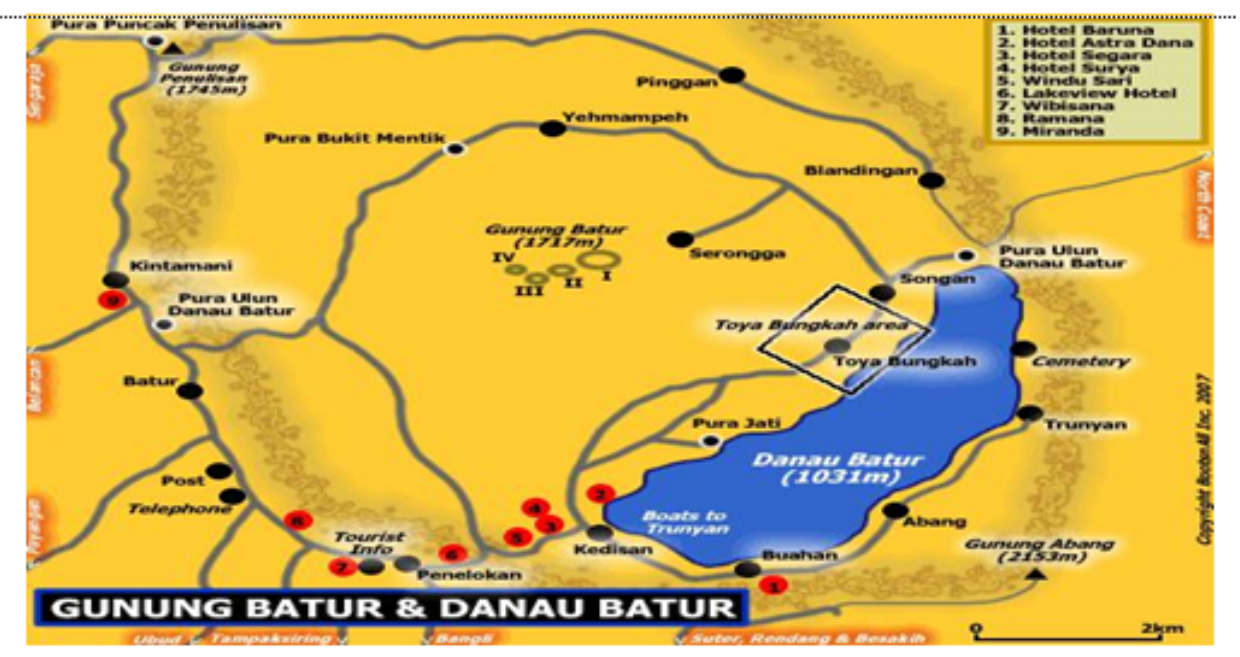

Gambar. 1.1 Peta Wilayah Desa Abang Batu Dinding Kec. Kintamani

Pada sektor pertanian masyarakat Desa Abang Batu Dinding sangat terkenal dengan tanaman holtikulturanya. Jenis tanaman holtikultura yang dikembangkan di wilayah Desa Abang Batu Dinding adalah, cabe lombok, cabe bali, jagung, kentang, kubis, tomat, bawang merah dan bawang putih yang menjadi primadona serta aneka sayuran lainnya. Aneka tanaman ini dapat ditanam sepanjang musim, baik musim hujan maupun musim kering. Pada musim hujan tanaman holtikultura menghandalkan air hujan untuk tumbuh dan berkebang, sedangkan dimusim panas masyarakat Desa Abang Batu Dinding memanfaatkan air danau untuk mengairi tanamannya. Proses mengairi tanaman sayuran dilakukan dengan menggunakan mesin penyedot air dan selang untuk mengirim air ketanaman yang akan diairi. Walapun demikian tidak semua areal pertanian dapat terjangkau dengan air danau di musim kemarau, sehingga hanya tanah-tanah disekitar danau saja yang dapat menanam tanaman holtikultura.

Selain sektor pertanian sektor utama penunjang kehidupan masyarakat Desa Abang Batu Dinding adalah sektor perikanan. Hal ini disebabkan karena wilayah Desa Abang Batu Dinding sebagian besar merupakan wilayah danau batur yang dapat dimanfaatkan untuk mengembangkan ikan air tawar. Pada awalnya masyarakat Desa Abang Batu Dinding, khususnya yang bergelut dalam bidang perikanan (ikan air tawar) atau nelayan hanya memanfaatkan ikan yang secara alami hidup dan berkembang di Danau Batur tanpa proses budidaya. Hasil tangkapan ikan dari Danau Batur pada awalnya sangat menggembirakan bahkan mampu memenuhi kebutuhan para nelayan untuk menyekolahkan anak-anak dan menghidupi rumah tangga. Namun seiring dengan semakin meningkatnya para nelayan dan kebutuhan ikan air tawar dari hari-kehari menyebabkan semakin menipisnya ikan yang hidup dan berkembang di Danau Batur. Bahkan ikan yang benar-benar siap untuk dipanen semakin hari semakin menipis, sehingga ikan yang sebenarnya belum siap untuk dipanen juga ditangkap oleh nelayan untuk dijual guna memenuhi kebutuhan hidup. Implikasinya ikan siap panen yang ada di Danau Batur tidak mampu memenuhi memenuhi permintaan pasar.

Salah satu usaha yang dilakukan oleh para nelayan di Desa Abang Batu Dinding Kecamatan Kintamani adalah dengan mengembangkan model pembudidayaan ikan air tawar dengan sistem kramba. Pembudidayaan ikan air tawar dengan sistem kramba membutuhkan modal yang sangat besar, mengingat bahan baku membuat kramba, biaya membuat kramba, benih ikan, pakan ikan dan biaya perawatan membutuhkan modal yang sangat besar. Pada awalnya hanya beberapa nelayan saja yang mempunyai kramba yaitu nelayan-nelayan yang memiliki modal. Kramba yang dibuatpun masih sangat kecil dengan kemampuan untuk membudidayakan ikan air tawar yang sangat terbatas. Berbagai persoalan terjadi berkaitan dengan pembudidayaan ikan kramba secara pribadi ini, khususnya berkaitan dengan modal usaha, pemeliharaan dan perawatan serta pembibitan. Bahkan beberapa kramba akhirnya tidak produktif karena proses pemeliharaan dan perawatan yang sangat menyulitkan. Akhirnya masyarakat Desa Abang Batu Dinding yang bergelut dalam bidang nelayan mengembangkan kelompok-kelompok nelayan yang membudidayakan ikan air tawar dengan sistem kramba. Ada beberapa keunggulan model pembudidayaan dengan sistem kramba ini, yaitu (1) ikan yang dipelihara dapat dikembangkan sesuai dengan keinginan dan kebutuhan, (2) cara pemeliharaan yang lebih mudah, karena terdapat dalam satu tempat, (3) masa panen dapat ditentukan sesuai dengan kebutuhan, (4) proses perawatan lebih mudah dilakukan dengan menggunakan sistem tugas anggota kelompok, (5) pemasaran ikan dapat dilakukan sesuai dengan pesanan dan permintaan, dan (6) lebih kecil membutuhkan modal usaha, karena dilakukan dengan urunan dari semua anggota kelompok, sehingga terasa lebih ringan. 

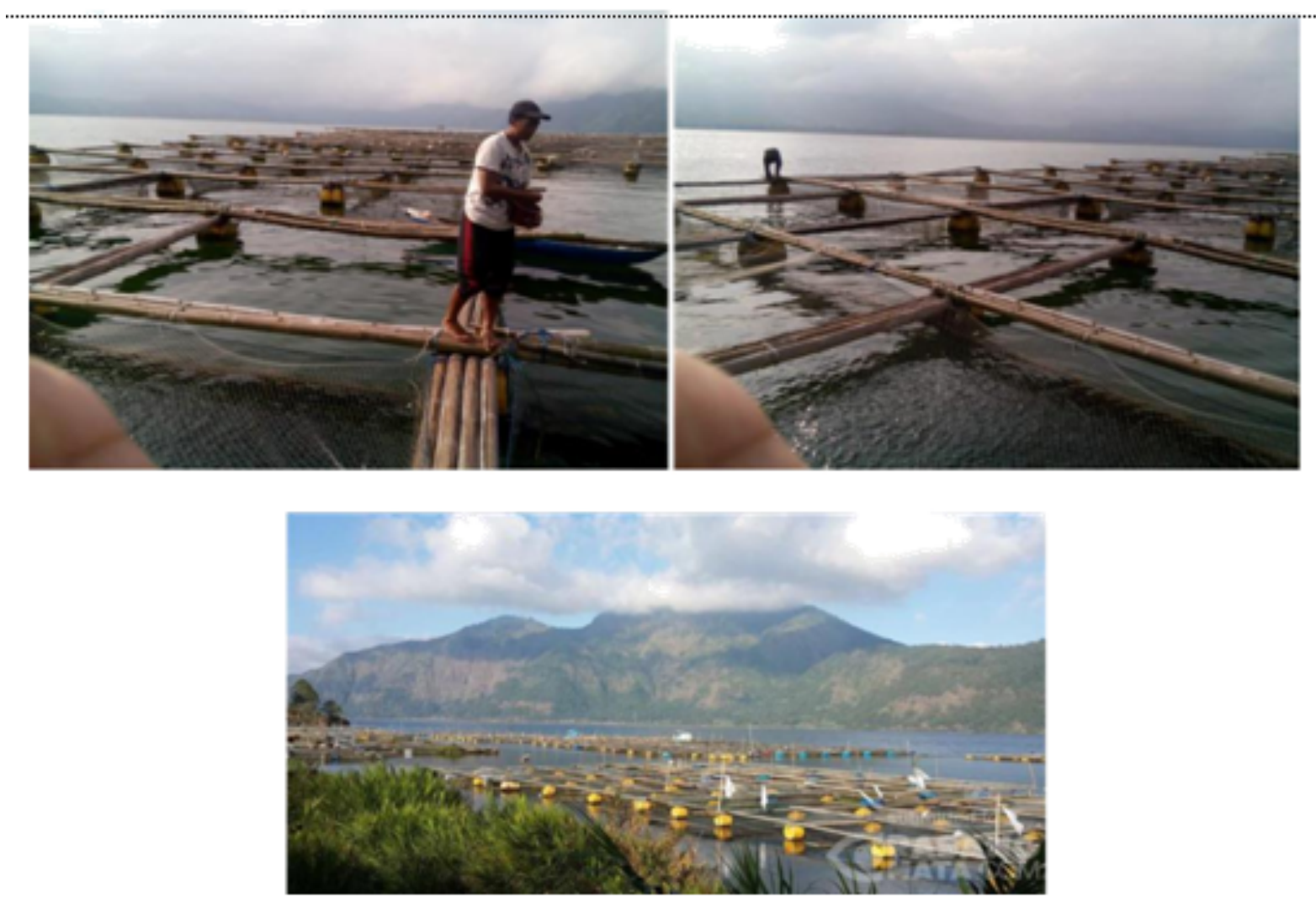

Gambar 1.2. Budi Daya Ikan Mujair di Danau Batur

Saat ini di Desa Abang Batu Dinding terdapat 7 (tujuh) kelompok nelayan ikan air tawar yang menggunakan sistem kramba untuk mebudidayakan ikan. Masing-masing kelompok ada yang beranggotakan 5 sampai 7 orang. Setiap kelompok memiliki satu buah kramba yang luasnya bisa mengcapai $1000 \mathrm{~m} 2$. Untuk dapat menjadi anggota kelompok masing-masing anggota kelompok diwajibkan membayar uang pangkal yang digunakan untuk membuat kramba, membeli bibit dan membeli pakan ikan. Sedangkan proses perawatan dilakukan dengan sistem pembagian tugas dan tangungjawab yang diberikan pada masing-masing anggota kelompok. Setiap anggota kelompok akan mendapatkan tugas yang sama untuk setiap siklusnya, mulai dari memberikan pakan ikan, melakukan perawatan ikan, memanen ikan dan menjual ikan hasil kramba. Setiap sebulan sekali, kelompok nelayan ikan air tawar ini mengadakan sangkep (musyawarah) untuk membicarakan berbagai hal yang berkaitan dengan persoalan nelayan, khususnya ikan air tawar yang dipelihara. Pembudidayaan ikan kramba dengan sistem kelompok ini sangat efektif dalam membudidayakan ikan air tawah di wilayah Danau Batur.

Beberapa potensi yang ada telah dicoba dikembangkan seperti badan usaha desa yang bergerak di bidang usaha pertanian dan bidang usaha budi daya ikan air tawar. Adanya badan usaha desa ini diharapkan mampu menjadi salah satu pergerakan perubahan perekonomian masyarakat dengan memanfaatkan sumber daya manusia dan sumber daya alam yang ada di Desa Abang Batu Dinding. Namun upaya yang di bangun oleh pemerintah kabupaten Bangli untuk membangun badan usaha desa di Desa Abang Batu Dinding ini menemui berbagai permasalahan, yaitu (1) Bidang Pendidikan, tingkat pendidikan masyarakat yang notabenanya keluarga kurang mampu sebagian besar belum memiliki kualifikasi pendidikan/keterampilan yang memadai, banyak anak putus sekolah akibat keadaan ekonomi dan jarak sekolah, kurangnya data manajemen dan kinerja sekolah, fasilitas sekolah yang kurang memadai dan kurang adanya guru yang professional dalam penunjang pendidikan; (2) Tatanan Masyarakat Desa, antara lain manajemen adminitrasi desa yang kurang, kurang adanya kegiatan-kegiatan di desa, keamanan lingkungan dan industry rumahan; (3) Perternakan dan Perikanan Air Tawar, antara lain kurang optimalnya sistem pemasaran hasil panen dari sektor pertanian dan perikanan yang masih dikendalikan oleh pengepul, kurang kreatifnya masyarakat dalam pengolahan hasil pertanian dan perikanan, sistem panen ikan yang masih sederhana dan tradisional, masyarakat belum bisa untuk melakukan pembibitan masih membeli dari balai pembenihan bibit ikan, (4) Pertanian dan perkebunan antara lain : sistem olah lahan dan pemeliharaan tanaman sayuran seperti kol, tomat, bawang merah, 
cabe merah besar, dan kacang buncis masih sangat tradisional, sistem pemasaran hasil pertanian dan perkebunan masih dikendalikan pengepul, kurang kreatifnya masyarakat dalam mengolah hasil pertanian dan perkebunan, (5) Industri Rumahan, kurang adanya inisiatif dan kreativitas masyarakat untuk membuka industri rumahan dari pengolahan hasil alam disana, seperti industri olahan tangkapan ikan (abon mujair, krupuk mujair dan bakso mujair), industri olahan pertanian, industri kerajinan dan keterampilan ( pembuatan batako, papin, ulatan bambu, dll ), (6) Bidang Pariwisata, masih terbatasnya tempat wisata, daerah wisata desa tua (Desa Trunyan), belum adanya rumah penginapan/hotel/villa yang memadai sehingga turis hanya lewat saja, pemandu wisata tracking dan haiking yang masih terbatas dan kurangnya pusat informasi wisata yang baik dalam bentuk pamplet maupun elektronik, (7) Bidang Sosial dan Hukum, di daerah ini pernah terjadi konflik antar desa akibat lahan pekerjaan sebagai pemandu wisata ke daerah trunyan, benih konflik harus diupayakan untuk ditekan, sehingga situasi ke depan selalu menjadi kondusif, untuk itu diperlukan penyuluhan-penyuluhan tentang sosial, hukum dan pendidikan karakter masyarakat disana, (8) Sistem Perekonomian dan Pemasaran, perekonomian masyarakat disana masih rendah, hanya menghandalkan penjualan hasil pertanian dan perikanan kepada pengepul yang selalu menekan masyarakat disana, kurangnya kemampuan dalam ilmu pemasaran untuk memasarkan hasil pertanian dan perikanan yang hasilnya bias lebih menjanjikan.

Berdasarkan uraian tersebut di atas, kondisi Desa Abang Batu Dinding dapat diilustrasikan sebagai berikut, (1) Potensi sumberdaya alam/lingkungan yang ada di Desa Abang Batu Dinding pada umumnya berupa lahan pertanian dan perikanan sistem keramba, lahan yang pertanian yang sangat subur dan perikanan yang sangat baik, tapi kurangnya potensi masyarakat disana dalam pengolahan hasil pertanian dan perikanan sistem keramba tersebut. (2) Kondisi lingkungan sangat jauh dari perkotaan dan pusat perekonomian, keterbatasan kendaraan, yang menyebakan kurang mendukungnya laju pembangunan dan sistem perekonomian secara serentak dan cepat di daerah tersebut, (3) Interaksi sosial antar warga sangat terbatas karena terbatasnya sarana dan prasarana yang menjadi kendala terhadap laju informasi yang semestinya bias diketahui dan diterima bersama, (4) Mata pencaharian penduduk Desa Abang Batu Dinding secara umum adalah Pertanian, Perkebunan, dan Perikanan dengan sistem keramba, sektor perikanan sistem keramba ini ditunjang dengan adanya kelompok-kelompok yaitu kelompok ikan mina sari, kelompok ikan wana giri, kelompok ikan pradi, kelompok ikan sari nadi dan banyak lagi kelompok-kelompok tani ikan di Desa Abang Batu Dinding, dan (5) Prospek potensi desa yang bias dikembangkan antara lain : Industri Rumahan dari hasil pertanian dan perikanan seperti bawang goring dalam kemasan, abon ikan mujair, bakso mujair, kerupuk mujair yang akan nantinya bias di gunakan sebagai oleh-oleh khas kintamani. erdasarkan potensi dan permasalahan yang ada pada masyarakat Desa abang Batu Dinding, tampaknya diperlukan upaya strategis yang bersifat fundamental, khsusunya yang menyangkut perubahan pola pikir masyarakat masyarakat Abang Batu Dinding.

Perubahan pola pikir ini dapat dilakukan melalui proses pelatihan dan pendampingan penguatan kearifan lokal masyarakat Desa Abang Batu Dinding. Pemberdayaan nilai-nilai lokal ini menyangkut peningkatan keberanian dan keterampilan masyarakat dalam mengembangkan usaha mandiri yang berbasis pada nilai-nilai lokal genius. Nilai-nilai lokal genius yang kuat pada masyarakat desa abang Batu Dinding adalah pola kekerabatan, gotong royong dan budaya jengah. Sedangkan kondisi alamiah yang dapat menjadi kekuatan lokal masyarakat Desa Abang Batu Dinding adalah panorama alam, pertanian, peternakan ikan dan latar danau Batur.Berdasarkan pada kearifan lokal tersebut tampaknya beberapa upaya strategis yang layak diterjadikan untuk memperkuat perekonomian masyarakat Desa Abang Batu Dinding adalah (1) pelatihan dan pendampingan pembuatan dan penggunaan pupuk organik untuk pertanian holtokultura berbasis kelompok tani, (2) pelatihan dan pendampingan pengembangan masakan tradisional berbahan dasar hasil perikanan dan perkebunan masyarakat setempat berbasis kelompok tani, (3) pelatihan dan pendampingan usaha mandiri (hume industry) berbasis dadya, (4) pelatihan dan pendampingan pengolahan makanan berbahan dasar ikan mujair, (5) pelatihan dan pendampingan pengembangan wisata pertanian dan wisata perikanan, (6) pelatihan dan pendampingan pengemasan produks pertanian, perikanan dan kuliner, dan (7) pelatihan dan pendampingan manajemen usaha dan pemasaran produks pertanian, perikanan dan kuiliner tradisional.

\section{Metode}

Mengingat kompleksnya permasalahan yang dihadapi oleh masyarakat Desa Abang Batu Dinding sebagai mana yang digambarkan di atas, maka disepakati beberapa persoalan prioritas yang akan diatasi melalui kegiatan desa binaan bagi masyarakat ini, yaitu masalah peningkatan potensi sumber daya manusia dengan potensi sumber daya alam yang ada, pembudidayaan ikan air tawar dan pertanian , masalah pengolahan ikan kramba dan hasil pertanian pasca panen dan pemasaran ikan keramba dan hasil pertanian pasca panen. Berdasarkan pada permasalahan prioritas tersebut, maka solusi yang ditawarkan 
melalui desa binaan ini menggunakan metode sebagai berikut : 1) Partisipatory Rural Appraisal (PRA) yaitu suatu sistem untuk menyusun dan mengembangkan program operasional dalam pembangunan tingkat desa. Metode ini ditempuh dengan memobilisasi sumber daya manusia dengan sumber daya alam yang ada. Konsep dari metode ini adalah melaksanakan identifikasi masalah baik program bidang pendidikan (keterampilan), bidang perikanan/pertanian, maupun bidang ekonomi. Metode ini diharapkan bisa membantu masyarakat untuk meningkatkan dan memanfaatkan potensi yang ada.

Enthrepreneurship Capasity Building (ECB), metode ini berkaitan erat dengan kemampuan beriwirausahan dari masyarakat, dengan metode ini diharapkan (1) memberikan wawasan, sikap dan keterampilan usaha, (2) memberikan peluang untuk membuka usaha dan pemberian modal, (3) memonitoring dan mengevaluasi bagaimana pengembangan usahanya. Dalam metode ini akan dilakukan pelatihan pengolahan hasil pertanian dan hasil pasca panen ikan keramba menjadi makanan siap saji (Abon Ikan Mujair, Kerupuk Ikan Mujair, Bakso Ikan Mujair dll), yang nantinya bisa menjadi usaha mandiri (home industry) bagi masyarakat di Desa Abang Batu Dinding. Pelatihan dan pendamping pengolahan produk pasca panen akan diberikan oleh pakar Pendidikan Kesejahteraan Keluarga (PKK) Undiksha (Dosen Jurusan Pendidikan Kesejahteraan Keluarga Undiksha). Pelatihan dan pendamping pengolahan produk pasca panen akan dimulai dengan memberikan materi tentang strategi pengolahan produk pasca panen, pelatihan pembuatan Abon Ikan Mujair, Kerupuk Ikan Mujair, Bakso Ikan Mujair khas Kintamani. Selama ini para nelayan hanya melakukan penjualan ikan setalah dipanen, sehingga dimasa-masa musim panen yang bersamaan terjadi akan terjada kelebihan produk, sehingga harga jualnya menjadi rendah. Hal ini menyebabkan para nelayan merugi, terlebih harga pakan dan perawatan yang semakin tinggi.

Teknologi Tepat Guna (TTG), yaitu metode yang dirancang bagi suatu masyarakat tertentu agar dapat disesuaikan dengan aspek-aspek lingkungan, keetisan, kebudayaan, sosial, politik dan ekonomi masyarakat bersangkutan. Metode Teknologi Tepat Guna ini haruslah menerapkan metode yang hemat sumber daya, mudah dirawat dan berdampak polutif minimalis dibandingkan dengan teknologi pada umumnya.

Untuk mengukur tingkat keberhasilan kegiatan yang telah dilakukan, maka akan dilakukan evaluasi minimal 3 (tiga) kali, yaitu evaluasi proses, evaluasi akhir, dan evaluasi tindak lanjut. Kegiatan evaluasi ini akan melibatkan tutor/pakar dari Undiksha Singaraja dan Dinas Kerajinan dan Perindustrian Kabupaten Bangli. Pada kegiatan Pemberdayaan Masyarakata Dalam Pengembangan Ekonomi Kreatif Berbasis Tri Hita Karana di Desa Binaan Desa Abang Batu Dinding Kecamatan Kintamani, masyarakat setempat akan dilibatkan dari awal sampai akhir kegiatan. Masyarakat Desa Abang Batu Dinding akan dilibatkan dalam merencanakan program, penjadwalan kegiatan, penyediaan bahan, khususnya ikan kramba yang dihasilkan, ikut serta dalam pelatihan sampai pada tahap uji coba produk pelatihan. Pelibatan Masyarakat Desa Abang Batu Dinding secara penuh ini diharapkan dapat memberikan seperangkat pengetahun dan keterampilan yang lengkap kepada masyarakat dalam melakukan pengemasan terhadap produk ikan kramba yang dihasilkan dan melakukan pengolahan pasca panen serta cara pengembangannya.

\section{Hasil Dan Pembahasan}

Sampai saat ini, pelatihan ini sudah dilaksanakan selama 4 bulan dilapangan atau (70\%) dari keseluruhan pelatihan. Pelatihan ini diikuti oleh 20 orang anak-anak usia dini untuk kegiatan pelatihan pendidikan nilai karakter anak usia dini dan 30 orang wanita untuk pelatihan kegiatan pengolahan ikan mujair seperti abon mujair, bakso mujair dan krupuk mujair dari desa Abang Batu Dinding Kintamani. Bahan ajar yang dipergunakan selama pelatihan terdiri dari bahan cetakan, berupa buku, poster, dan brosur. Selain bahan tercetak, juga digunakan bahan pembelajaran audio visual. Bahan audio visual ditayangkan dengan LCD proyektor, sehingga dapat lebih menarik perhatian peserta.

Untuk mengukur tingkat keberhasilan kegiatan yang telah dilakukan, maka dilakukan evaluasi terhadap pengetahuan dan ketrampilan yang dimilikinya. Evaluasi tidak dilakukan dengan menyediakan waktu khusus. Tapi penilaian dilakukan secara berkesinambungan oleh para tim pengelola. Penilaian diberikan dalam bentuk angka, yang berisikan prestasi dalam bidang pengetahuan dan keterampilan. Lembar nilai akhir, akan diletakkan di belakang STTP, dengan format sebagai berikut. 


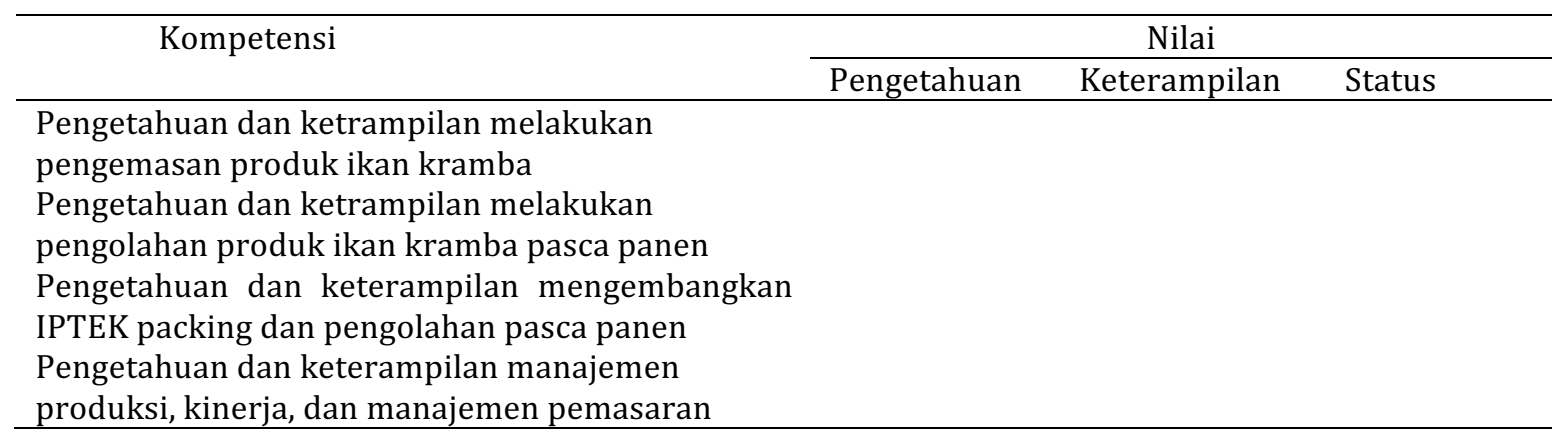

Nilai diberikan dalam rentang $50 \mathrm{~s} / \mathrm{d} 100$. Peserta berstatus lulus jika memperoleh nilai lebih dari 75. Dari 30 peserta pelatihan yang mengikuti program ini, pelatihan dianggap berhasil jika $95 \%$ peserta dapat menyelesaikan seluruh program pelatihan. Dari keseluruhan lulusan, program dianggap berhasil jika 80\%-nya mampu memanfaatkan pengetahuan yang diperoleh ke dalam kehidupan sehari-hari yang pada akhirnya akan dapat meningkatkan kehidupan perekonomian mereka. Untuk menyukseskan penyelenggaraan program tidak terlepas dengan prosedur birokrasi yang dilakukan oleh tim pelaksana dari Universitas Pendidikan Ganesha (UNDIKSHA). Langkah program yang tim pelaksana rancang diantaranya meliputi: (1) koordinasi, (2) pelaksanan, dan (3) evaluasi. Langkah awal yang tim pelaksana lakukan adalah rapat koordinasi tahap awal untuk merancang pertemuan dan koordinasi,dilanjutkan dengan rapat untuk merancang pelaksanaan kegiatan tahap awal.

Setelah kesepakatan waktu ditentukan untuk melakukan koordinasi dengan aparatur Pemerintah Desa Abang Batu Dinding Kecamatan Kintamani, Kabupaten Bangli. Proses administrasi yang tim pelaksana program harus penuhi yaitu meliputi, secara bertim sebelumnya berkoordinasi dengan Lembaga Penelitian dan Pengabdian Masyarakat (LPPM) untuk meminta surat pengantar kegiatan pengabdian dan surat perjalanan dinas resmi yang substansinya memuat Permohonan untuk Mengadakan Pengabdian Pada Masyarakat sesuai dengan rencana kegiatan Pengabdian Pada Masyarakat (P2M) dengan materi 1) Pelatihan pendidikan nilai karakter terhadap anak usia dini, 2) Meningkatkan kesadaran masyarakat akan potensi alam dan lingkungan memalui kegiatan pembudidayaan ikan mujair dan pertanian organik untuk mewujudkan kesejahteraan masyarakat dan pembangunan berkelanjutan, 3) Mendorong tumbuhnya kreativitas, motivasi dan inovasi masyarakat dalam mengatasi permasalahanpermasalahan yang dihadapi melalui pelatihan pengembangan usaha ekonomi kreatif, seperti pengolahan ikan mujair pasca panen menjadi Abon Mujair, Krupuk Mujair, Bakso Mujair dan pengolahan hasil pertanian seperti bawang menjadi bawang goreng siap saji, dan 4) Meningkatkan kesadaran masyarakat melalui penyuluhan untuk mendorong terwujudnya kemandirian dan kesejahteraan masyarakat dalam bidang sistem pemasaran hasil sumber daya alam yang ada.

Alur birokrasi pelaksanaan program dengan mendatangi langsung desa tujuan P2M skim Desa Binaan dan bersilaturahmi dengan aparatur desa setempat. Adapun hasil koodinasi tim dengan birokrasi Pemerintahan Desa Abang Batu Dinding Kintamani, diantaranya: kesepakatan jadwal kegiatan, tempat penyelenggaraan, agenda kegiatan, termasuk pedataan peserta pelatihan dari masing-masing dusun di Desa Abang Batu Dinding Kintamani dikoordinir oleh Drs. I Gede Nurjaya, M.Pd. dan Kadek Rai Suwena, S.Pd., M.Pd dan dibantu oleh Ida Bagus Sidartha Manuaba, SE peternak ikan mujair kintamani. Program yang kami rancang dan usulkan untuk diselenggarakan di Desa Abang Batu Dinding Kintamani memperoleh apresiasi yang sangat luar biasa dari Pemerintah Desa setempat beserta jajarannya. Mengingat baru pertama kali Desa Abang Batu Dinding Kintamani disasar kegiatan pengabdian dengan melibatkan warga masyarakat untuk mampu diberdayakan melalui kegiatan sosialisasi dan pelatihan dari pihak LPM Undiksha. Secara langsung dengan penuh penghargaan dan penghormatan Kepala Desa beserta staf menyambut kami dengan tangan terbuka dan mengucapkan terima kasih kepada LPM Undiksha karena sudah bersedia memfasilitasi warga Desa Abang Batu Dinding Kintamani dengan penerjunan staf ahli yang berkompeten melalui penyelenggaraan kegiatan P2M. Harapan dari output program P2M yang tim pelaksana selenggarakan dan diharapkan kepada warga masyarakat yang dalam hal ini diwakili oleh masyarakat Desa Abang Batu Dinding Kintamani Desa Abang Batu Dinding Kecamatan Kintamani Kabupaten Bangli.

Pada pelatihan ini materi disampaikan oleh pakar pengolahan ikan Ni Wayan Sukerti, S.Pd, M.Pd. (dosen tata boga Universitas Pendidikan Ganesha), beliau banyak menyampaikan materi tentang berbagai macam olahan ikan mujair. Pelatihan ini dilaksanakan pada tanggal 11 dan 18 Juni 2016 bertempat di balai desa Abang Batu Dinding Kintamani yang diikuti oleh 30 orang peserta. Peserta sangat antusias mengikutinya. Pendidikan dan pelatihan dilaksanakan melalui metode praktek langsung pengolahan bahan baku, bambu, dan sebagainya sehingga siap menjadi bahan dasar produk kreatif yang selanjutnya 
digunakan pada usaha kelompok. Beberapa olahan yang dipraktikan adalah bakso ikan mujair, abon ikan mujair, krupuk mujair dan mujair goreng dan bakar dengan aneka bumbu nyat nyat, pedas, asam, dan lain-lain. Dalam pelaksanaan diklat ini tidak ditemukan kendala yang berarti karena respon yang sangat bagus dari masyarakat yang mengikuti pelaksanaan kegiatan ini. Pelaksanaan pelatihan berjalan dengan lancar dan baik terlihat dari besarnya perhatian dari anggota kelompok dalam menyimak serta memperhatikan materi-materi yang disampaikan sekaligus praktek langsung meracik dan mengolah adonan. Hasil pelatihan menunjukkan bahwa dari 30 orang yang ikut pelatihan 25 orang $(83,33 \%)$ masuk dalam kategori sangat mengetahui dan terampil dalam pengolahan produk ikan kramba pasca panen, 2 orang $(2,66)$ termasuk dalam kategori kategori mengetahui dan terampil dalam pengolahan produk ikan kramba pasca panen, dan 5 orang $(16,66)$ termasuk dalam kategori cukup mengetahui dan terampil dalam pengolahan produk ikan kramba pasca panen.

Kegiatan ini terlaksana tanggal 11 Juni sampai dengan 13 Juni 2016 dengan pendampingan dari tim pelaksana P2M. Oerientasi kegiatan pengembangan IPTEK packing hasil pengolahan ikan mujair bertujuan untuk meningkatkan nilai jual hasil olahan mujair yang sudah dibuat oleh masyarakat menjadi lebih tertata, lebih terlihat bersih dan rapi sehingga layak untuk dijual di pasar-pasar. Agenda kegiatan berupa pengemasan abon, bakso, dan krupuk ikan dengan plastik, dan pemberian lebel. Plastik yang digunakan dipilih sesuai dengan daya tahan makanan.

Salah satu alat yang digunakan adalah mesin hand sealer. Mesin ini digunakan untuk mengemas abon, bakso, dan krupuk ikan yang dibungkus dengan kemasan plastik. Pengoperasian mesin hand impulse sealer dilakukan menggunakan tangan secara manual dan sangat mudah. Anda cukup meletakan plastik kemasan diantara hand sealer tersebut, lalu di tekan layaknya mesin press. Dengan menggunakan mesin pengemas hand sealer, makanan Anda dapat bertahan lebih lama karena tersimpan rapat dalam plastik.

Pelaksanaan pelatihan berjalan dengan lancar dan baik terlihat dari besarnya perhatian dari anggota kelompok dalam menyimak serta memperhatikan materi-materi yang disampaikan sekaligus praktek langsung meracik dan mengolah adonan. Hasil pelatihan menunjukkan bahwa dari 30 orang yang ikut pelatihan 20 orang $(66,67 \%)$ masuk dalam kategori sangat mengetahui dan terampil dalam mengembangkan IPTEK packing dan pengolahan pasca panen, $5(16,66)$ orang termasuk dalam kategori kategori mengetahui dan terampil dalam mengembangkan IPTEK packing dan pengolahan pasca panen, dan 5 orang $(16,66)$ termasuk dalam kategori cukup mengetahui dan terampil dalam mengembangkan IPTEK packing dan pengolahan pasca panen.

Setelah diberikan pelatihan oleh tim pelaksana dari Undiksha Singaraja, masyarakat Desa Abang Batu Dinding Kintamani Kecamatan Kubu dapat memahami dengan jelas materi pelatihan mengenai tata boga dalam hal mengolahan hasil tangkapan ikan mujair yang semula keterampilan mengolahnya tidak dikuasai dan sekarang menjadi dikuasai dapat dipraktekannya menjadi beragam jenis olahan produk hasil karya olahan kuliner yang telah dilakukan pendampingan dari pihak tim pelaksana Desa Binaan Mujair Desa Abang Batu Dinding Kintamani. Diklat pengelolaan ikan mujair ini bertujuan untuk menunjang tingkat pengetahuan dan wawasan masyarakat tentang pemberdayaan kawasan pesisir secara tepat guna. Keunggulan yang dapat dilihat dali pelaksanaan program, bahwa berdasarkan hasil evaluasi tidak lanjut juga terekam, beberapa manfaat praktis yang diperoleh oleh masyarakat Desa Abang Batu Dinding Kintamani melalui Pelatihan Tata Boga Pengelolaan Ikan Mujair, yaitu: (1) mereka mendapatkan informasi yang jelas dan utuh mengenai hakekat pemberdayaan masyarakat dari segi pengetahuan dan keterampilan, bermakna untuk penciptaan lapangan pekerjaan baru yang sifatnya inovatif dari pengolahan ikan mujair; (2) masyarakat Desa Abang Batu Dinding Kintamani yang menjadi peserta pelatihan memperoleh gambaran yang jelas mengenai langkah pengembangan iklim usaha dengan memanfaatkan komoditas hasil tangkapan ikan secara swadaya; (3) peserta pelatihan juga mendapatkan gambaran yang jelas dan utuh tentang manfaat hasil tangkapan ikan apabila dikelola dengan baik akan mendatangkan nilai finansial apabila telah diolah menjadi aneka olahan kuliner ikan mujair sebagai menu handalan.

Keseluruhan proses transfer iptek ini dilaksanakan dengan pola pelatihan dan pendampingan terhadap masyarakat Desa Abang Batu Dinding Kintamani yang meliputi: Tata Boga, dan Tata Cara Pengurusan Ijin Usaha. Pelatihan dengan pendampingan terhadap proses produksi, dan tata cara pengurusan ijin usaha, sehingga diharapkan kegiatan P2M yang diselenggarakan dapat menyasar penguasaan pengetahuan dan keterampilan Kelompok masyarakat Desa Abang Batu Dinding Kintamani secara berkesinambungan.

Kendala pelaksanaan program adalah sulitnya meminid waktu untuk pencapaian kesepakatan pelaksanaan kegiatan, karena umumnya peserta latihan terbentur dengan rutinitas pekerjaan harian yang menunjang perekonomian keluarga, maupun pelaksanaan kegiatan ritual adat-istiadat yang lumayan padat di Desa Abang Batu Dinding Kintamani dalam kaitannya dengan paruman desa adat untuk 
penyelenggaraan ritual keagamaan sebagaimana layaknya masyarakat Hindu Bali pada umumnya. Jadi, untuk bisa mengkoordinir warga perlu koordinasi intensif dengan pihak kesra dan segenap jajarannya. Berkaitan dengan pengkondisian peserta program, walaupun dijumpai kendala masalah waktu selama tim pelaksana program mampu mengatasinya dengan melakukan koordinasi secara intensif dengan Kepala Desa Abang Batu Dinding Kintamani, staf Kesra Desa Abang Batu Dinding Kintamani, dan segenap jajaran terkait masyarakat Desa Abang Batu Dinding Kintamani. Program ini masih berlangsung dan masih banyak terdapat kekuarangan-kekurangan yang ada dalam pengabdian ini. Terutama untuk mengukur keberhasilan pengimplementasian dari kurikulum yang sudah dirancang.

\section{Simpulan Dan Saran}

Kesimpulan yang dapat diperoleh dari pelaksanaan program pengabdian ini adalah: 1) Tingkat partisipasi yang tinggi dari mitra program pengabdian kepada masyarakat memberikan dampak positif bagi pelaksanaan program, terlihat dari kehadiran peserta yang tanpa ijin, dan dukungan dari kepala desa. 2) Hasil pelatihan menunjukkan bahwa dari 30 orang yang ikut pelatihan 25 orang (83,33\%) masuk dalam kategori sangat mengetahui dan terampil dalam pengolahan produk ikan kramba pasca panen, 2 orang $(2,66)$ termasuk dalam kategori kategori mengetahui dan terampil dalam pengolahan produk ikan kramba pasca panen, dan 5 orang $(16,66)$ termasuk dalam kategori cukup mengetahui dan terampil dalam pengolahan produk ikan kramba pasca panen. 3) Hasil pelatihan menunjukkan bahwa dari 30 orang yang ikut pelatihan 20 orang $(66,67 \%)$ masuk dalam kategori sangat mengetahui dan terampil dalam mengembangkan IPTEK packing dan pengolahan pasca panen, $5(16,66)$ orang termasuk dalam kategori kategori mengetahui dan terampil dalam mengembangkan IPTEK packing dan pengolahan pasca panen, dan 5 orang $(16,66)$ termasuk dalam kategori cukup mengetahui dan terampil dalam mengembangkan IPTEK packing dan pengolahan pasca panen. 4) Kendala pelaksanaan program adalah sulitnya meminid waktu untuk pencapaian kesepakatan pelaksanaan kegiatan, karena umumnya peserta latihan terbentur dengan rutinitas pekerjaan harian yang menunjang perekonomian keluarga, maupun pelaksanaan kegiatan ritual adat-istiadat yang lumayan padat di Desa Abang Batu Dinding Kintamani dalam kaitannya dengan paruman desa adat untuk penyelenggaraan ritual keagamaan sebagaimana layaknya masyarakat Hindu Bali pada umumnya.

Untuk pelaksanaan selanjutnya akan dilakukan dengan koordinasi dan persipaan yang lebih matang sehingga tidak ada kendala-kendala yang berarti dalam pelatihan selanjutnya, serta hasilnya menjadi lebih berkualitas.

\section{Daftar Pustaka}

Dasman, $\quad$ Raymon. 1980. Prinsip Ekologi Untuk Pembangunan, Terjemahan Idjah Soemarwoto. Jakarta: Gramedia.

Gerungan. 1988. Psikologi Sosial. Bandung: Unesco.

Karama dan Abdurrachman. 1995. Kebijakan Nasional dalam Penanganan Lahan Kritis di Indonesia. Yogyakarta: BPTP Prosiding Seminar Rekayasa Teknologi Konservasi.

Kurana. 2008. Sukses Mengembangkan Wirausaha. Jakarta: Grsindo.

Kurniasih Dian. 2006. Pengaruh Daya Dukung Lahan dan Faktor Sosial Ekonomi terhadap Perilaku Petani dalam Konservasi Lahan Pertanian di Kabupaten Kulon Progo. Yogyakarta: Program Studi Ekonomi Pertanian, Jurusan Ilmu-Ilmu Pertanian, UGM.

Muhadjir, N. 1993. Kepemimpinan Adopsilnovasi untuk Pengembangan Masyarakat. Yogyakarta: Rake Press.

Negara Republik Indonesia. Undang-Undang Nomor 5 Tahun 1999 tentang Larangan Praktek Monopoli dan Persaingan Usaha Tidak Sehat. Lembaran Negara Nomor 33, TLN RI Nomor 3817. Pemerintah Kabupaten Karangasem. Data Statistik Desa Tianyar Tahun 2011. Karangasem: Tianyar.

Suhardjo. 1988. Peranan Kelembagaan dalam Hubungannya dengan Komersialisasi Usahatani dan Distribusi Pendapatan Wilayah Kabupaten Banjar Negara Jawa Tengah. Disertasi (tidak dipublikasikan). Yogyakarta: UGM. 
Soemarwoto, Otto. 2001. Ekologi, Lingkungan Hidup, dan Pembangunan. Jakarta: Penerbit Djambatan. Susanto, P.Astrid. 1983. Pengantar Sosiologi dan Perubahan Sosial. Jakarta: Bina Cipta. 